\title{
Optimization of Lasers Parameters for Marking Cylindrical Shanks from SC and Cermet
}

\section{Miroslav Zetek, Martin Mrázek, Ivana Zetková}

Faculty of Mechanical Engineering, University of West Bohemia. Univerzitní 8, 30614 Pilsen. Czech Republic. E-mail: mzetek@rti.zcu.cz,mrma@students.zcu.cz, zetkova@rti.zcu.cz

Industrial laser marking of the parts is used for the long life identification. For these the micro engraving and annealing are used. The main requirements for the marking are visibility, readability, stability and especially surface without surface modification or defects. In case of the cutting tools main marking are made on the cutting tool shank so it is necessary to use the correct parameters of the marking setup. The marking must be made without change of accuracy and surface quality. When the bad parameters are used the sharp edges are created on the edge of the descriptions. These edges cause gradually damage of the clamping surface and it causes gradually loss of clamping accuracy. So it is a very important to use optimal parameters which depend on the marking material. These article deal with process optimization of the laser marking parameters when the sintered carbide and cermet are used. The laser parameters like laser power, scanning speed and frequency were change and surface quality was evaluated by the optical microscope IFM G4.

Keywords: Laser marking, sintered carbide, cermet, surface quality

\section{Acknowledgement}

The present contribution has been prepared under project LO1502'Development of the Regional Technological Institute' under the auspices of the National Sustainability Programme I of the Ministry of Education of the Czech Republic aimed at supporting research, experimental development and innovation.

\section{References}

[1] BRAJER J., MÁDL J., ŠVÁBEK R., PITRMUC Z., ROSTOHAR D, ZEMAN P., OCAÑA J. L. (2015). Application of Laser Shock Processing. In: Manufacturing Technology. Vol. 15, pp. 278-285. Univerzita J. E. Purkyne, Czech Republic

[2] ŠRAMHAUSER K., KUŚMIERCZAK S. (2016). Laser Hardening of the Functional Surfaces of Machine Tools. In: Manufacturing Technology. Vol. 16, pp. 248-253. Univerzita J. E. Purkyne, Czech Republic

[3] ZRAK A., KOŇÁR R., JANKEJECH P. (2015). Influence of Chemical Composition in Steel on Laser Cutting Stability. In: Manufacturing Technology. Vol. 15, pp.748-752. Univerzita J. E. Purkyne, Czech Republic

[4] LUKOVICS, I., MALACHOVA, M. (2012). Laser machining of chosen materials. In: Manufacturing Technology, Vol. 12, pp. 38-42. Univerzita J. E. Purkyne, Czech Republic

[5] PIERETTI, E.F., das Neves, M.D.M. (2016). Influence of laser marks on the electrochemical behaviour of the ASTM F139 stainless steel for biomedical application. In: International Journal of Electrochemical Science, Vol. 11, pp. 3532-3541. Electrochemical Science Group, Brazil

[6] PIERETTI, E.F., COSTA, I. (2013). Surface characterisation of ASTM F139 stainless steel marked by laser and mechanical techniques. In: Electrochimica Acta, pp. 838-843. Elsevier Ltd, Brazil

[7] VElotTi, C., ASTARITA, A., LEONE, C., GENNA, S., MINUTOLo, F.M.C., SQUILLACE, A. (2016) Laser Marking of Titanium Coating for Aerospace Applications. In: Procedia CIRP, pp. 975-980. Elseviere, Italy

[8] LAGO, J., GUAGLiAnO, M., NOVỲ, F., BOKUVKA, O. (2016). Influence of Laser Shock Peening Surface Treatment on Fatigue Endurance of Welded Joints from S355 Structural Steel. In: Manufacturing Technology, Vol. 16, pp. 154-159. Univerzita J. E. Purkyne, Czech Republic

[9] PODANÝ, J., MOLOTOVNIK, A. (2014). 3D measurement of surface texture parameters. In: Manufacturing Technology, Vol. 14, pp. 596-600. Univerzita J. E. Purkyne, Czech Republic

[10] KUNDRAK, J., FELHO, C. (2016). 3D roughness parameters of surfaces face milled by special tools. In: Manufacturing Technology, Vol. 16, pp. 532-538. Univerzita J. E. Purkyne, Czech Republic

[11] MIČIETOVÁ, A., NESLUŠAN, M., ČILLIKOVÁ, M., KOLǍ̌íK, K. (2016). Barkhausen noise emission of surfaces after plasma beam machining. In: Manufacturing Technology, 16 (1), pp. 178-183. Univerzita J. E. Purkyne, Czech Republic. 